\title{
The timing of benthic copepod emergence
}

\begin{abstract}
We investigated emergence of marine benthic harpacticoid and cyclopoid copepods from subtidal sediment into the bottom water. Previous studies that used traps in the field found that copepods emerged from the sediment within $2 \mathrm{~h}$ of dusk. We examined emergence in 20-min sampling periods over $13 \mathrm{~h}$ from 1200 to $0100 \mathrm{~h}$ in a laboratory flume under conditions of constant flow speed. The light intensity was adjusted to field conditions every $20 \mathrm{~min}$. We observed a peak in emergence during the 20-min sampling period after the onset of darkness, greatly increasing the accuracy with which the timing of emergence is known. This result will help to set the stage for studies of emergence cues.
\end{abstract}

Temporary emergence of benthic animals into the water column (hereafter emergence) characterizes many taxa, including amphipods (DeWitt 1987), copepods (Walters and Bell 1986), benthic ostracods, and platyhelminthes (Armonies 1988a). Copepods were the focus of the experiment reported here because they are the predominant meiofaunal emergers (Walters 1988; Armonies 1989), emerging in abundances of $>50,000$ individuals $\mathrm{m}^{-2} \mathrm{~d}^{-1}$ in some locations (Thistle 2003).

Emergence of benthic copepods plays a role in benthicpelagic coupling because benthic copepods that feed in the water column and return to the seabed bring water column resources to the benthos, and benthic copepods in the water column that are consumed by pelagic predators move benthic resources into the water column (Walters and Bell 1986). Also, emergence has important consequences for copepod ecology. Emerging copepods are entrained in water flow and do not return to the same location they left (Service and Bell 1987; Palmer 1988). This displacement affects the organization of the copepod community and might explain the high recolonization rates of defaunated patches (Palmer and Gust 1985).

Copepod emergence has been studied on a variety of temporal scales, including seasonal, lunar, and tidal, but the diel emergence cycle has been a particular focus. Armonies (1989) found that more copepods emerged during the night than during the day. Several studies have measured emergence of harpacticoid copepods at 6-h intervals and found higher abundances in the water column during night and the highest rate of emergence during sunset (Walters and Bell 1986; but see Hicks and Coull 1986 for an exception). Walters $(1988,1991)$ and Walters and Bell (1994), who observed emergence patterns at 2-h intervals, found that the sunset sampling period had the highest number of emergers. Their results suggest that emergence peaks during the 2 -h period beginning at dusk, but this level of resolution could be inadequate to elucidate the cues for this behavior. Environmental conditions that have been shown to influence copepod emergence, such as the intensity of the incident light and pore-water oxygenation (Armonies 1988b), change rapidly over periods much shorter than $2 \mathrm{~h}$ (Revsbech et al.
1981). The correlation of changes in the chemical and physical conditions in the habitat with copepod emergence can be better discerned if behavior and environmental conditions are examined as nearly as possible on the same timescale. Greater resolution of the timing of copepod emergence is therefore needed. Our goal was to study the emergence of benthic copepods at a temporal resolution of $20 \mathrm{~min}$, higher than any used previously, to set the stage for studies of cues and causes.

Material and methods-Location: The study site was on the north Florida shelf $\left(29^{\circ} 52.169^{\prime} \mathrm{N}\right.$; $\left.084^{\circ} 26.428^{\prime} \mathrm{W}\right)$ in the Gulf of Mexico at a water depth of $5 \mathrm{~m}$. The seabed was unvegetated, well-sorted, medium sand with a mean grain size of $0.38 \pm 0.02 \mathrm{~mm}(n=5$, Fig. 1a). The water content was $25.07 \pm 2.94 \%$; organic material was $0.77 \pm 0.14 \%$. Wave orbital motion reached the seafloor episodically during periods of high wind speed. Under continuing wave action, oscillating bottom currents generated sediment ripples. The site was defined by two permanent, parallel, 10-m transect ropes separated by $3 \mathrm{~m}$ (area $\left.=30 \mathrm{~m}^{2}\right)$. The transect lines and a movable, 3-m cross-line were marked every $10 \mathrm{~cm}$, forming a Cartesian coordinate system for sampling. The diel light regime at the sediment surface was determined by measurement of the photosynthetically active radiation (PAR, 400-700 nm) with an underwater quantum sensor (LI-192SA, LI-COR Environmental). The sensor housing was buried such that the sensing head was coplanar with the sediment surface. A LI-1000 data logger recorded the mean light intensity averaged over $5 \mathrm{~min}$ and the minimum and maximum light intensity from $0200 \mathrm{~h}$ on 21 September to $0200 \mathrm{~h}$ on 25 September 2001. These measurements revealed that onset of darkness at the sediment surface occurred at $\sim 1845 \mathrm{~h}$ and that the average daily maximum intensity of the incident PAR was $217 \pm 78 \mu \mathrm{mol}$ quanta $\mathrm{m}^{-2} \mathrm{~s}^{-1}$. A sample measurement is shown in Fig. 1b. A miniature data logger (StowAway Tidbit, Onset Computer Corporation) deployed at the sediment surface recorded the seawater temperature from 20 September to 29 November 2001. The highest temperature of $28.6^{\circ} \mathrm{C}$ was measured on 23 November; the lowest temperature was $17.25^{\circ} \mathrm{C}$ on 30 October (Fig. 1c).

Laboratory flume: The flume described in Foy and Thistle (1991) was used with some modifications. The seawater in the flume ( $\sim 1,000$ liters, $30-\mu \mathrm{m}$ filtered) was adjusted to in situ temperature with a chiller (Aquatic Ecosystems part AE7D) and to in situ salinity with Instant Ocean ${ }^{\circledR}$. Three sediment samples in black-painted acrylic tubes $\left(15.5 \mathrm{~cm}^{2}\right.$ $\times 10 \mathrm{~cm}$, see below for sampling procedure) were inserted $50 \mathrm{~cm}$ from the outflow of the duct, $4 \mathrm{~cm}$ apart in the center of the duct ( $5 \mathrm{~m}$ long, $0.5 \mathrm{~m}$ wide), on a line perpendicular to the flow. After the sediment samples were inserted, seawater flowed from the head tank through a T-shaped diffuser 

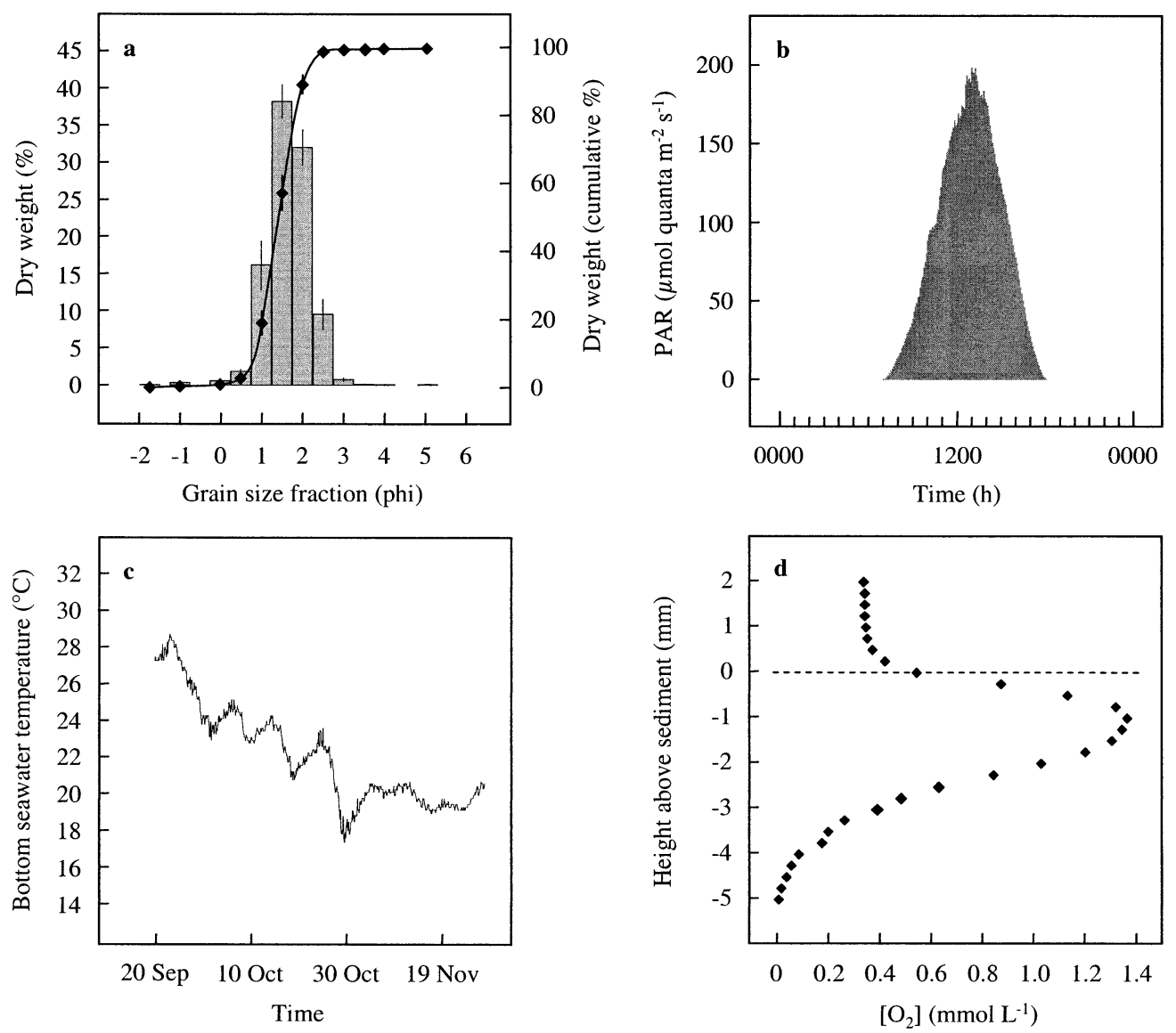

Fig. 1. Abiotic parameter at the sampling site. (a) The grain size distribution for the upper 6mm-thick sediment layer. The bars represent the dry weight, and the line represents the cumulative dry weight. The error bars are $\pm 1 \mathrm{SD}$. (b) PAR at the sediment surface from $0000 \mathrm{~h}$ on 10 Nov to $0000 \mathrm{~h}$ on $11 \mathrm{Nov} 2001$. The intensity of PAR was maximal at $\sim 1400 \mathrm{~h}$ and decreased essentially linearly until sunset. (c) Bottom seawater temperature from 20 Sep to 29 Nov 2001. (d) Vertical $\left[\mathrm{O}_{2}\right]$ profile measured on 9 Nov 2001 between 1250 and $1350 \mathrm{~h}$ at $130 \pm 10 \mu \mathrm{mol}$ quanta m${ }^{-2} \mathrm{~s}^{-1}$ PAR and a temperature of $20.5^{\circ} \mathrm{C}$. The dashed line represents the sediment surface.

and a flow straightener to fill the duct to a depth of $8 \mathrm{~cm}$. A removable sieve with $30-\mu \mathrm{m}$ mesh was located in the outflow below the duct. Copepods that left the sediment were swept away by the flow and caught in the sieve. The flow speed was much slower than needed to erode the sediment. To characterize the seawater flow above the surface of the sediment sample, we measured flow-speed microprofiles with a microelectrode (FS20, Unisense A/S; see Vopel et al. 2002). The flow speed microelectrode and $\mathrm{O}_{2}$ microelectrodes (see below) were mounted on a micromanipulator (Märzhäuser Wetzlar) driven by stepping motors and moved vertically by a wired remote control in $200-\mu \mathrm{m}$ increments.

Light regime: We chose a light regime that was representative of a typical day at the field site. A 750-watt halogen light (ETC Source Four) was suspended $50 \mathrm{~cm}$ above the test sediment. We placed a blue filter gel of known spectral properties (Rosco Filter \#69, Brilliant Blue) in front of the light to simulate the light spectrum at $5 \mathrm{~m}$ depth. To measure the intensity of the PAR in the flume, we inserted the light sensor into a corer hole and filled the flume with $8 \mathrm{~cm}$ of seawater. We repeated this procedure for each corer hole, and we could not detect a difference among them. During the experiment, light intensity was held constant at $200 \mu \mathrm{mol}$ quanta $\mathrm{m}^{-2} \mathrm{~s}^{-1}$ for the first hour (from $1200 \mathrm{~h}$ until $1300 \mathrm{~h}$ ) and then decreased in a stepwise fashion by $11 \mu \mathrm{mol}$ quanta $\mathrm{m}^{-2} \mathrm{~s}^{-1}$ every $20 \mathrm{~min}$ until $1840 \mathrm{~h}$, when the light was switched off.

Sediment pore-water oxygenation: To assess our ability to mimic geochemical conditions, we measured profiles of pore-water $\left[\mathrm{O}_{2}\right]$ with microelectrodes $(\mathrm{OX} 50$, Unisense $\mathrm{A} / \mathrm{S}$; Revsbech 1989) across the sediment-water interface in the field and in the flume. The output current was measured and converted to a millivolt signal by an underwater picoammeter (PA3000U, Unisense $\mathrm{A} / \mathrm{S}$ ) and transferred to a data logger (OM-3000, Omega ${ }^{\circledR}$ Engineering). For the field measurements, a manually operated micromanipulator (Märzhäuser Wetzlar) was attached to an aluminum post that had been driven into the sediment.

Sediment sampling: Seven replicates of the experiment were carried out on different days (five in October and two 
Table 1. The number of copepods that were caught in the sieve and the number of copepods that remained in the cores over seven replicates. The former values are based on the number caught divided by the surface area of the three cores $\left(=46.5 \mathrm{~cm}^{-2}\right)$ and then normalized to $10 \mathrm{~cm}^{-2}$. Note that sieve values were estimated from three cores but that sediment values were estimated from only one of the three.

\begin{tabular}{|c|c|c|c|c|c|c|c|c|}
\hline & \multicolumn{7}{|c|}{ Copepods (individuals per $10 \mathrm{~cm}^{-2}$ ) } & \multirow[b]{2}{*}{ Mean \pm SD } \\
\hline & 1 & 2 & 3 & 4 & 5 & 6 & 7 & \\
\hline In sieve & 91.6 & 104.3 & 123.9 & 126.0 & 73.1 & 111.6 & 98.7 & $104.2 \pm 17.2$ \\
\hline \multicolumn{9}{|l|}{ In sediment $(\mathrm{mm})$} \\
\hline $0-2$ & 11.6 & 45.8 & 107.7 & 139.4 & 63.2 & 82.6 & 106.5 & $79.5 \pm 39.9$ \\
\hline $2-4$ & 6.5 & 3.2 & 23.9 & 11.0 & 76.1 & 123.9 & 12.9 & $36.8 \pm 42.4$ \\
\hline $4-6$ & 3.2 & 7.7 & 17.4 & 29.7 & 47.7 & 70.3 & 51.6 & $32.5 \pm 23.1$ \\
\hline $6-8$ & 5.8 & 4.5 & 16.1 & 23.9 & 53.5 & 67.1 & 34.2 & $29.3 \pm 22.1$ \\
\hline $8-10$ & 11.6 & 0.6 & 7.7 & 15.5 & 20.0 & 39.4 & 9.7 & $14.9 \pm 11.4$ \\
\hline $10-20$ & 110.3 & 13.5 & 74.2 & 40.0 & 12.9 & 121.9 & 39.4 & $58.9 \pm 41.0$ \\
\hline $20-30$ & 65.2 & 12.3 & 94.2 & 85.5 & 85.8 & 97.4 & 25.8 & $66.6 \pm 31.8$ \\
\hline $30-40$ & 43.9 & 46.5 & 81.9 & 86.5 & 51.0 & 89.0 & 38.1 & $62.4 \pm 20.7$ \\
\hline Total in sediment & 258.1 & 134.2 & 423.2 & 431.6 & 410.3 & 691.6 & 318.1 & $381.0 \pm 161.1$ \\
\hline Total & 349.7 & 238.5 & 547.1 & 557.6 & 483.4 & 803.2 & 416.8 & $485.2 \pm 166.5$ \\
\hline
\end{tabular}

in November 2001). For a given replicate, scuba divers took three cylindrical sediment samples at random from the study site between $0910 \mathrm{~h}$ and $0926 \mathrm{~h}$, each $15.5 \mathrm{~cm}^{2}$ by $10 \mathrm{~cm}$ deep. Thereafter, temperature and $\mathrm{pH},\left[\mathrm{O}_{2}\right]$, and salinity of the bottom water were measured with PortaMess 912 (Knick), Oxi 196, and LF23 (WTW) meters, respectively. During transit, the sediment samples were kept in a seawater bath at approximately in situ temperature and light intensity. A filter of the same type used in the flume covered the bath to mimic the in situ spectrum of the PAR. The sediment samples were in place in the laboratory flume $<60 \mathrm{~min}$ after collection and before $1200 \mathrm{~h}$ (Eastern Daylight Time). At that time, the light was set to deliver $200 \mu \mathrm{mol}$ quanta $\mathrm{m}^{-2}$ $\mathrm{s}^{-1} \mathrm{PAR}$, which corresponded to typical noon intensity at the seafloor of the sampling site (see below).

Flume sampling: We collected the copepods that had been caught in the sieve every $20 \mathrm{~min}$ for $13 \mathrm{~h}$ starting at 1200 h. For each 20-min period, temperature, salinity, and $\mathrm{pH}$ of the seawater directly upstream of the sediment sample were measured as in the field. All animals caught on a sieve were
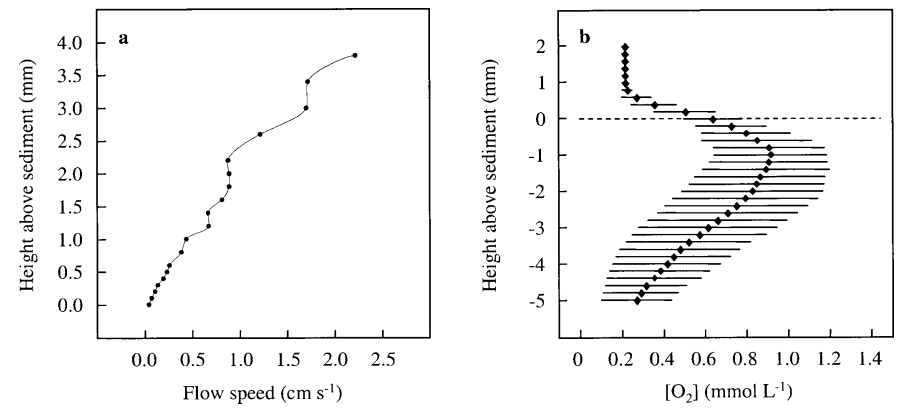

Fig. 2. Abiotic parameter in the flume. (a) Microprofile of flow speed above a sediment sample. (b) Average vertical $\left[\mathrm{O}_{2}\right]$ profile calculated from profiles that were measured across the sedimentwater interface of five sediment cores at $1215 \mathrm{~h}$ when the light was $200 \mu \mathrm{mol}$ quanta $\mathrm{m}^{-2} \mathrm{~s}^{-1}$. The error bars are $\pm 1 \mathrm{SD}$. The dashed line represents the sediment surface. rinsed off and preserved in sodium borate-buffered, 30- $\mu \mathrm{m}-$ filtered seawater formaldehyde $(9: 1, \mathrm{v} / \mathrm{v})$. At $0100 \mathrm{~h}$, we selected one sediment sample at random for further analysis. The sediment was sliced at 2-mm intervals for the first centimeter and at 10-mm intervals for the second through fourth centimeters. The slices were preserved as above. All samples were stained in rose Bengal, and harpacticoid and cyclopoid copepods were removed under a dissecting microscope. The harpacticoids were separated into adults and juveniles, and the adult harpacticoids were separated by sex.

Results-Abiotic parameters in situ: During sampling, the temperature of the bottom seawater ranged from $18^{\circ} \mathrm{C}$ to $23^{\circ} \mathrm{C}$, the salinity from 32 to 35 , the $\mathrm{pH}$ from 8.1 to 8.2 , and $\left[\mathrm{O}_{2}\right]$ from 230 to $244 \mu \mathrm{mol} \mathrm{L}{ }^{-1}$. Onset of darkness (as measured at the sediment surface) during the study occurred between 1815 and $1830 \mathrm{~h}$. From 21 October to 13 November 2001, the maximum intensity of PAR ranged between 197 and $229 \mu \mathrm{mol}$ quanta $\mathrm{m}^{-2} \mathrm{~s}^{-1}$ at the sediment surface. We measured the $\left[\mathrm{O}_{2}\right]$ in the sediment pore water in the field on 9 November 2001 between 1250 and $1350 \mathrm{~h}$. The weather was calm, and the light intensity at the sediment surface was $130 \pm 10 \mu \mathrm{mol}$ quanta $\mathrm{m}^{-2} \mathrm{~s}^{-1}$. The $\left[\mathrm{O}_{2}\right]$ was highest $(1,362$ $\mu \mathrm{mol} \mathrm{L}{ }^{-1}$ ) at $1 \mathrm{~mm}$ below the sediment surface (Fig. 1d) and decreased to $5 \mu \mathrm{mol} \mathrm{L}{ }^{-1}$ at $5 \mathrm{~mm}$ below the sediment surface, the greatest depth measured.

Abiotic parameters in the laboratory flume: The temperature of the seawater in the flume ranged from $17^{\circ} \mathrm{C}$ to $23^{\circ} \mathrm{C}$, the salinity from 32 to 34 , the $\mathrm{pH}$ from 7.9 to 8.1 , and the $\left[\mathrm{O}_{2}\right]$ from 219 to $262 \mu \mathrm{mol} \mathrm{L}{ }^{-1}$. The flow in the flume was laminar and unidirectional, increasing in speed from $\sim 0 \mathrm{~cm}$ $\mathrm{s}^{-1}$ at the sediment surface to $2.2 \mathrm{~cm} \mathrm{~s}^{-1} 3.8 \mathrm{~mm}$ above the sediment surface (Fig. 2a). An average $\left[\mathrm{O}_{2}\right]$ microprofile across the interface between the sediment sample and the flume seawater is shown in Fig. 2b. This profile was calculated from five $\left[\mathrm{O}_{2}\right]$ profiles (one profile each for five of the seven replicates), taken at $1215 \mathrm{~h}$ when PAR was 200 $\mu \mathrm{mol}$ quanta $\mathrm{m}^{-2} \mathrm{~s}^{-1}$. The average $\left[\mathrm{O}_{2}\right]$ was highest at $1 \mathrm{~mm}$ 


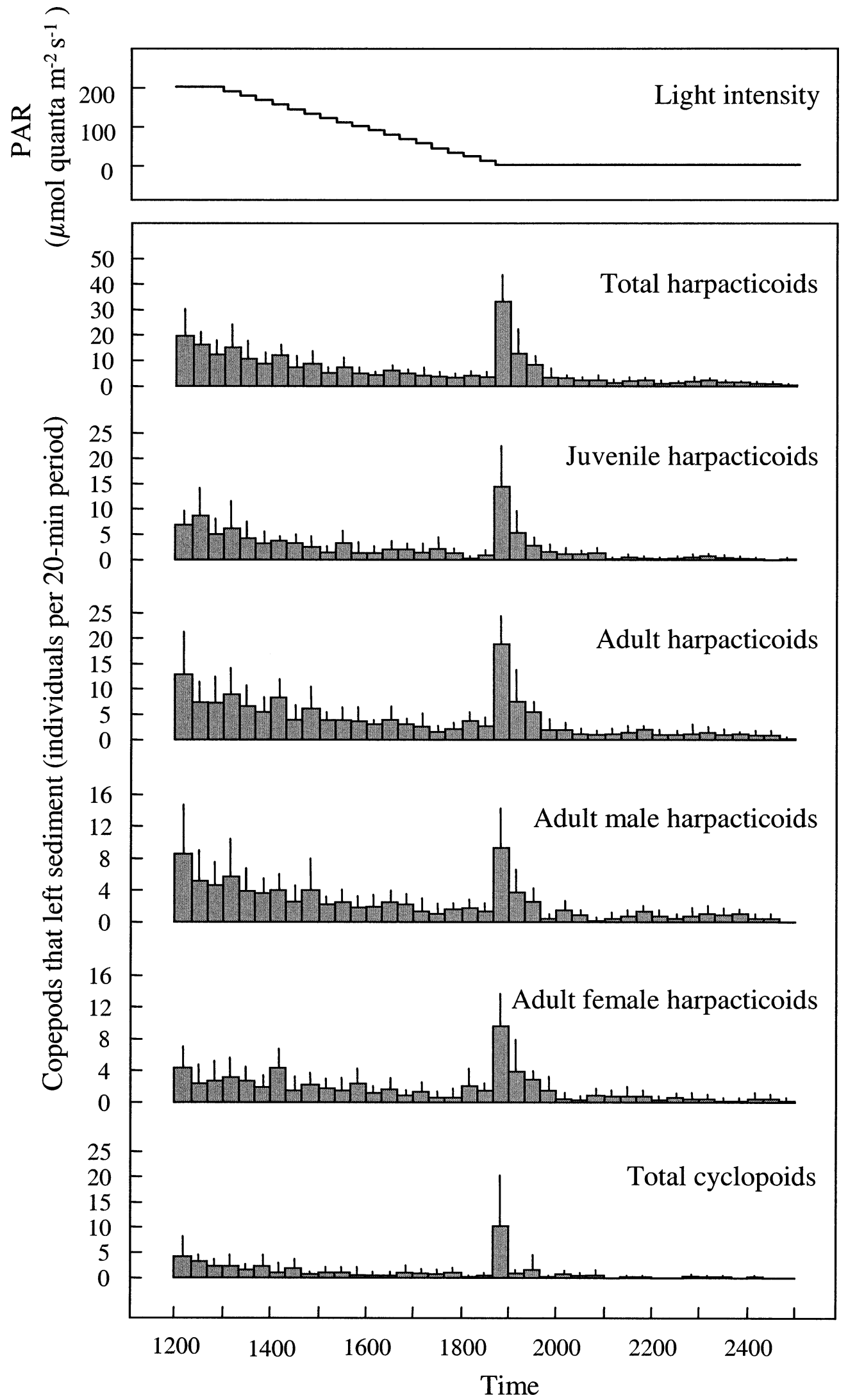

Fig. 3. Average number $(n=7)$ of all harpacticoids combined-juvenile harpacticoids, adult harpacticoids, adult male harpacticoids, adult female harpacticoids-and total cyclopoids that left the sediment during each 20-min sampling period. 
depth $\left(915 \mu \mathrm{mol} \mathrm{L}{ }^{-1}\right)$ and decreased to $269 \mu \mathrm{mol} \mathrm{L}{ }^{-1}$ at 5 mm depth.

Copepod emergence: The sediment contained an average of $485 \pm 167$ copepods $10 \mathrm{~cm}^{-2}(n=7)$, of which an average of $104 \pm 17$ individuals per $10 \mathrm{~cm}^{2}(21.5 \%)$ left the sediment during the experiment (Table 1). The upper 10mm-thick layer of the sediment samples had the highest number of copepods, and within that layer, the $0-2-\mathrm{mm}$ layer had the most. The numbers of individuals that were caught in the sieve were divided into six categories and are presented in Fig. 3. Of all the copepods that left the sediment, an average of $78 \% \pm 6 \%$ were harpacticoids, and an average of $52 \% \pm 8 \%$ of those were adults. The male to female ratio of adult harpacticoids was $1: 0.7$. Very few cyclopoids were found in the sediments at the end of the experiment.

Timing of emergence: The sampling period during which the most copepods left the sediment was from 1840 to 1900 h $(15.2 \%$ of those that left the sediment between 1200 and $0100 \mathrm{~h}$ ), the first interval when the PAR intensity was 0 $\mu$ mol quanta $\mathrm{m}^{-2} \mathrm{~s}^{-1}$. This pattern is the same for total harpacticoids, adult harpacticoids, adult male harpacticoids, adult female harpacticoids, juvenile harpacticoids, and cyclopoids (Fig. 3). During this sampling period, $76 \%$ of the animals leaving the sediment were harpacticoids, $57 \%$ of which were adults of which $49 \%$ were male. The 20 -min segment during which the second highest number of copepods left the sediment was at $1200-1220 \mathrm{~h}(8.3 \%$ of those that left the sediment between 1200 and $0100 \mathrm{~h}$ ). This period was followed by a steady decrease in the number of copepods caught in the sieve per 20-min interval until $1840 \mathrm{~h}$.

Discussion-Benthic copepod emergence: Although our approach allowed a more detailed temporal assay than had been done previously, interpretation of our results was not straightforward. Our procedures collected animals that left the cores because they emerged but also collected animals that left the cores inadvertently. That is, the normal movements of benthic copepods would be expected to take them, from time to time, to the sediment-water interface and to the edge of the core, where they risk being transported by the flow onto the flume bed and then into the sieve. Thus, an animal in our sieve could have been collected because it emerged or because it was inadvertently caught in the flume flow.

Inspection of Fig. 3 reveals three groups of sampling periods, those before $1840 \mathrm{~h}$ (PAR was decreased from 11 to $0 \mu \mathrm{mol}$ quanta $\mathrm{m}^{-2} \mathrm{~s}^{-1}$ at $1840 \mathrm{~h}$ ), those from 1840 to 1940 $\mathrm{h}$, and those after $1940 \mathrm{~h}$. The first and third groups can be seen to form a trend that is interrupted by the second group. We suggest that the trend arises from the steady loss (= background loss) of copepods from our cores. The decrease in the number lost per 20-min period is reasonable because no source of benthic copepods was available to replace those lost. The results for the periods between 1840 and $1940 \mathrm{~h}$ must be explained differently. From the work of Walters and Bell (1986) and Walters (1991), an emergence peak near sunset was expected. We interpret the excess of benthic co- pepods collected above background between 1840 and 1940 $\mathrm{h}$ as emergence.

The resolution of previous studies was on the scale of hours. Our 20-min timescale results revealed a single peak in benthic copepod emergence. The emergence peak began at local darkness, it was less than $1 \mathrm{~h}$ in duration, and the largest number of copepods emerged during the first 20-min period (i.e., 1840-1900 h). Using a shorter sampling period, we might have found that the duration of the emergence peak is even shorter. From Fig. 3, the emergence peak appears to be a response to light or to a factor indirectly controlled by light, such as $\mathrm{pH}$ or pore-water $\left[\mathrm{O}_{2}\right]$. If so, then the timing of the peak will depend on the rate of light attenuation at the seabed and should vary with depth, water clarity, and season.

To begin to assess the ecological consequences of benthic copepod emergence, we estimated the number of copepods that emerged during the 1-h peak. To do so, we estimated the amount of background loss during each of the three 20min periods that constituted the peak and subtracted those values from the observed number of animals collected during the corresponding periods. The background losses in the periods adjacent to the peak differed little. We therefore calculated a linear regression based on the four periods immediately before the peak and the four periods immediately after the peak. (The regression results changed very little if a few more points around the peak were included.) We found that $\sim 12,000$ copepods $\mathrm{m}^{-2}$ emerged during the 1 -h peak. (This estimate is likely conservative because copepods inadvertently lost before $1840 \mathrm{~h}$ might have emerged between 1840 and $1900 \mathrm{~h}$.) This value is similar to the $10^{4}-10^{5} \mathrm{co}-$ pepods $\mathrm{m}^{-2}$ Walters and Bell (1994) found leaving the sediment during their 2-h, postsunset sampling periods, suggesting that a substantial flux of benthic copepods occurs predictably in a relatively short time in some coastal waters. This flux appears to create an opportunity for water column predators at the onset of darkness. If so, emergence would contribute to benthopelagic coupling. In a different vein, benthic copepods apparently participate in pore-water mixing as other meiofauna and microfauna do, thereby stimulating microbial mineralization (Aller and Aller 1992; Glud and Fenchel 1999; Rysgaard et al. 2000). After large numbers of copepods leave the sediment in the hour after the onset of darkness, the intensity of pore-water mixing is likely to be reduced and with it, the rates of solute transport and the microbial mineralization.

Our discoveries about the timing of emergence will allow investigations of emergence cues to be focused on the time around dusk. Future experiments must confront the problem that light might be a direct cue, an indirect cue (via porewater chemistry), or a combination of the two. That is, manipulative experiments will be needed to decouple light intensity from the other parameters that could cue emergence.

Michael Teasdale

Department of Oceanography

Florida State University

Tallahassee, Florida 32306-4320

\footnotetext{
${ }^{1}$ Corresponding author (k.vopel@niwa.co.nz).
} 
Kay Vopel $^{1}$

National Institute of Water and Atmospheric Research

P.O. Box 11-115

Hamilton, New Zealand

David Thistle

Department of Oceanography

Florida State University

Tallahassee, Florida 32306-4320

\section{References}

Aller, R. C., AND J. Y. Aller. 1992. Meiofauna and solute transport in marine muds. Limnol. Oceanogr. 37: 1018-1033.

Armonies, W. 1988a. Active emergence of meiofauna from intertidal sediment. Mar. Ecol. Prog. Ser. 43: 151-159.

. 1988b. Physical factors influencing active emergence of meiofauna from boreal intertidal sediment. Mar. Ecol. Prog. Ser. 49: 277-286.

- 1989. Meiofaunal emergence from intertidal sediment measured in the field: Significant contribution to nocturnal planktonic biomass in shallow waters. Helgol. Mar. Res. 43: 29-43.

DeWITT, T. H. 1987. Microhabitat selection and colonization rates of a benthic amphipod. Mar. Ecol. Prog. Ser. 36: 237-250.

Foy, M. S., AND D. ThISTLE. 1991. On the vertical distribution of a benthic harpacticoid copepod: Field, laboratory, and flume results. J. Exp. Mar. Biol. Ecol. 153: 153-163.

Glud, R. N., AND T. FEnCHEL. 1999. The importance of ciliates for interstitial solute transport in benthic communities. Mar. Ecol. Prog. Ser. 186: 87-93.

Hicks, G. R. F., AND B. C. Coull. 1986. Distribution and behavior of meiofaunal copepods inside and outside seagrass beds. Mar. Ecol. Prog. Ser. 31: 159-170.

\section{Acknowledgments}

I. Hoedl, L. Sedlacek, and K. Suderman helped in the design and running of the experiment and C. Hippolyte, G. Hurst, L. Sedlacek, and A. Vopel helped with the sorting. The comments of A. B. Thistle improved the manuscript. This research was supported by ONR grant N00014-00-1-007.
PALMER, M. A. 1988. Dispersal of marine meiofauna: A review and conceptual model explaining passive transport and active emergence with implications for recruitment. Mar. Ecol. Prog. Ser. 48: $81-91$.

, AND G. Gust. 1985. Dispersal of meiofauna in a turbulent tidal creek. J. Mar. Res. 43: 179-210.

Revsbech, N. P. 1989. An oxygen microelectrode with a guard cathode. Limnol. Oceanogr. 34: 472-476.

- , B. B. JøRGENSEN, AND B. B. BRIX. 1981. Primary productivity of microalgae in sediments by oxygen microprofile, $\mathrm{H}^{14} \mathrm{CO}_{3}^{-}$fixation, and oxygen exchange methods. Limnol. Oceanogr. 26: 717-720.

Rysgatrd, S. P., P. B. Christensen, M. V. Sørensen, P. Funch, AND P. BERG. 2000. Marine meiofauna and nitrogen mineralization in sandy and soft sediments of Disko Bay, West Greenland. Aquat. Microb. Ecol. 21: 59-71.

Service, S. K., AND S. S. Bell. 1987. Density-influenced active dispersal of harpacticoid copepods. J. Exp. Mar. Biol. Ecol. 114: $49-62$.

ThISTLE, D. 2003. Harpacticoid copepod emergence at a shelf site in summer and winter: Implications for hydrodynamic and mating hypotheses. Mar. Ecol. Prog. Ser. 248: 177-185.

Vopel, K., C. H. Reick, G. Arlt, M. Pöhn, and J. A. Ott. 2002. Flow microenvironment of two marine peritrich ciliates with ectobiotic chemoautotrophic bacteria. Aquat. Microb. Ecol. 29: $19-28$.

WALTERS, K. 1988. Diel vertical migration of sediment-associated meiofauna in subtropical sand and seagrass habitats. J. Exp. Mar. Biol. Ecol. 117: 169-186.

- 1991. Influence of abundance, behavior, species composition, and ontogenetic stage on active emergence of meiobenthic copepods in subtropical habitats. Mar. Biol. 108: 207-215.

, AND S. S. BELL. 1986. Diel patterns of active vertical migration in seagrass meiofauna. Mar. Ecol. Prog. Ser. 34: 95103.

, AND - 1994. Significance of copepod emergence of benthic, pelagic, and phytal linkages in a subtidal seagrass bed. Mar. Ecol. Prog. Ser. 108: 237-249.

Received: 22 October 2003

Accepted: 5 January 2004

Amended: 18 January 2004 